\title{
Article \\ Phytoremediation Capability and Copper Uptake of Maize (Zea mays L.) in Copper Contaminated Soils
}

\author{
Ali Daryabeigi Zand ${ }^{1, *}$ and Karl H. Mühling ${ }^{2, *(D)}$ \\ 1 School of Environment, College of Engineering, University of Tehran, Tehran 1417853111, Iran \\ 2 Institute for Plant Nutrition and Soil Science, Kiel University, Hermann Rodewald Strasse 2, \\ D-24118 Kiel, Germany \\ * Correspondence: adzand@ut.ac.ir (A.D.Z.); khmuehling@plantnutrition.uni-kiel.de (K.H.M.); \\ Tel.: +98-21-61113154 (A.D.Z.); +49-431-8803189 (K.H.M.)
}

check for updates

Citation: Daryabeigi Zand, A.; Mühling, K.H. Phytoremediation Capability and Copper Uptake of Maize (Zea mays L.) in Copper Contaminated Soils. Pollutants 2022, 2, 53-65. https://doi.org/10.3390/ pollutants 2010007

Academic Editor: Massimo Trotta

Received: 21 December 2021

Accepted: 13 January 2022

Published: 1 March 2022

Publisher's Note: MDPI stays neutral with regard to jurisdictional claims in published maps and institutional affiliations.

Copyright: (C) 2022 by the authors. Licensee MDPI, Basel, Switzerland. This article is an open access article distributed under the terms and conditions of the Creative Commons Attribution (CC BY) license (https:// creativecommons.org/licenses/by/ $4.0 /)$.

\begin{abstract}
Copper is a frequently used heavy metal worldwide and known to be an essential micronutrient for most living organisms including plants. However, excessive levels of copper in soil may adversely affect plant growth and survival. The continuing introduction of copper to soil, e.g., through excessive utilization of agrochemicals has raised serious environmental concerns throughout the world. A variety of plants have the capability to eliminate pollutants from soil through different mechanisms; however, limited information is reported on phytoremediation potential of maize (Zea mays L.) and its uptake and the accumulation potential in copper-containing soils. The effects of additions of $0,50,100,200$ and $300 \mathrm{mg} \mathrm{kg}^{-1}$ of copper to soil on growth parameters of Z. mays, copper uptake from soil and accumulation in roots and shoots, and phytoremediation potential of Z. mays were investigated in this research. Copper content in soil and plant samples were determined using atomic absorption spectrophotometry. The addition of $50 \mathrm{mg} \mathrm{kg}^{-1} \mathrm{Cu}$ stimulated Z. mays growth parameters, while higher content of $\mathrm{Cu}$ exhibited inhibitory effects of plant growth. Results indicated that roots accumulated significantly higher levels of $\mathrm{Cu}$ than shoots in all treatments, suggesting dominancy of phytostabilization mechanism in remediation of $\mathrm{Cu}$-polluted soil by Z. mays. However, translocation of $\mathrm{Cu}$ from the roots to the aerial parts enhanced to some extent with copper level in soil. The greatest $\mathrm{Cu}$ accumulation capacity of $5210 \mu \mathrm{g}$ per pot was gained in Z. mays cultivated in soil treated with $200 \mathrm{mg} \mathrm{kg}^{-1}$ copper. Results demonstrated that Z. mays can promisingly remediate low to moderately copper-contaminated soils.
\end{abstract}

Keywords: Z. mays; copper; phytoremediation

\section{Introduction}

Heavy metal contamination and their probable impacts on the food chain have been associated with a wide range of human health risks. The accumulation of heavy metals in a soil matrix can significantly endanger human health as well as other living organisms life [1]. Despite many organic contaminants that can be biodegraded or naturally attenuated in the environment, heavy metals may not be degraded through natural processes and therefore tend to be continuously accumulated in the environment $[2,3]$. The occurrence of heavy metals in agricultural soil, which can be caused by various activities such as fertilization with fertilizers containing heavy metals, may endanger human health due to the vulnerability of water resources and food chain. In other words, soil contamination with heavy metals disrupts natural ecosystem services and ultimately adversely affects the human health through food chain [4]. Heavy metals can also negatively affect central nervous system posing mental disorder and damage other vital organs such as liver and lungs, thereby promoting an array of diseases for humans. Several adverse impacts of heavy metals of human health have been reported in the literature [5,6].

Heavy metals have also been recognized to endanger food security due to the rapid rise in industrial and agricultural activities, over population as well as disruption of natural 
ecosystems [3]. It is documented that millions of sites with the area of more than 20 million ha have been contaminated with various contaminants worldwide, with over fifty percent of them affected by heavy metals or metalloids [7,8]. Main causes of soil contamination with heavy metals include, but not limited to, metal plating and finishing operations, manure, biosolids, sewage sludge, industrial wastewater, pesticides, herbicides, fertilizers, and waste dumping [9]. Among them, agrochemicals play a significant role in the contamination of agricultural soils. Agrochemicals, which are mainly being used in organic agriculture contain remarkable levels of some heavy metals, e.g., copper sulfate $[10,11]$. Heavy metals may enter the agro-ecosystem through natural (e.g., soils having high background levels of such elements) and/or anthropogenic processes (e.g., application of phosphate fertilizers, sewage sludge, urban runoff, etc.) [12]. An excessive application of agrochemicals to crops contributes to the accumulation of chemicals in soil matrix and plant exposure [9]. Copper $(\mathrm{Cu})$ is a frequently used metal worldwide and its small quantities are considered to be essential to promote survival of plant species. Copper is a vital micronutrient for all plant species and its deficiency can suppress plant growth. However, high levels of copper occurrence in soil due to excessive utilization of some agrochemicals may exhibit toxic effects. Numerous studies have reported the $\mathrm{Cu}$-induced growth inhibition, oxidative damage and antioxidant response in agricultural food crops such as wheat, rice, maize, sunflower and cucumber [13]. Excessive $\mathrm{Cu}$ levels in soil can induce formation of reactive oxygen species (ROS) and interference with plant's respiration and photosynthesis [14].

Typically, the required copper level for healthy growth and development of plant species may vary with plant type [15]. Excessive concentrations of $\mathrm{Cu}$ in plants may reach crucial levels at which negative effects including molecular, physiological and morphological symptoms occur in plants at all growth stages. For instance, germination of wheat (Triticum aestivum L.) cultivated on filter papers in Petri dishes was reduced by $46 \%$ in presence of 500 ppm Cu after one day of incubation [16] and shoot height of rice declined by $48 \%$ in soil treated with $1000 \mathrm{mg} \mathrm{kg}^{-1} \mathrm{Cu}$ compared to the control [17]. Accumulation potential and nonbiodegradability of copper in soil make it detrimental to plant life and human health at high concentrations [18-20]. Therefore, possibility of removal of excessive amounts of copper from soil using maize (Z. mays) was investigated in this research. Z. mays was selected because it is known as a tolerant and fast-growing plant species which has been successfully employed in various phytoremediation studies [21,22] and its seeds can be readily accessed and cultivated in most parts of the world with pretty low maintenance requirements.

Designing and applying various approaches to remove toxic contaminants from soil has been an area of interest over the last decades [23]. Various remediation methods, including physicochemical and biological techniques, have been introduced for removal of contaminants from soil; however, proper selection and application of a remediation strategy should be made based on factors such as technical/financial constraints and nature of pollutants in an affected site. In situ and ex situ decontamination approaches are being practiced to remediate heavy metal contaminated soils. The ex situ approaches such as pump-and-treatment, thermal desorption, and vitrification are mainly energy intensive and costly [24,25]. In addition, some hazardous chemicals may be used in such remediation methods; therefore, implying further potential risks to the environment [26]. Nowadays, there is an extensive need in removal of high levels of heavy metals from soil using ecologically sound and cost-effective remediation approaches. Phytoremediation is an ecologically acceptable technology through which synergistic effect of plants and their associated microorganisms promotes remediation of soil affected with different organic and inorganic contaminants, e.g., heavy metals [27]. It is also known as a green biotechnology, facilitating removal of a wide range of substances from different media. A wide range of brownfields such as fertilized farmlands, oil refineries, waste disposal sites, power plants and agricultural sites can be managed using phytoremediation [28].

This research aimed to investigate the remediation of $\mathrm{Cu}$-contaminated soil by phytoremediation. The impact of different contents of copper on the biomass of Z. mays; uptake and 
translocation of $\mathrm{Cu}$ in $\mathrm{Z}$. mays cultivated in $\mathrm{Cu}$-contaminated soil; accumulation capacity and remediation capability of $Z$. mays to remediate copper were evaluated in this study. High concentrations of $\mathrm{Cu}$ in soil may suppress $\mathrm{Z}$. mays growth; however, if the plant can still establish sufficient biomass, extraction of enough $\mathrm{Cu}$ from soil can be expected. Therefore, the hypothesis of the present study was to ensure that, despite reduction in the growth of $\mathrm{Z}$. mays by $\mathrm{Cu}$ toxicity, sufficient biomass is still produced to extract sufficiently high amounts of $\mathrm{Cu}$ from the soil.

\section{Materials and Methods}

\subsection{Preparation and Characterization of Soil}

The used soil was collected from a depth of 0-30 $\mathrm{cm}$ from a non-metal-contaminated region in Southern part of Tehran, Iran. The gravel and large debris were removed by passing the soil through a $2 \mathrm{~mm}$ sieve, before being air-dried at $22-25{ }^{\circ} \mathrm{C}$ for 7 days. Different levels of $\mathrm{Cu}\left(\mathrm{SO}_{4}\right) \cdot 5 \mathrm{H}_{2} \mathrm{O}$ were added to $150 \mathrm{~mL}$ distilled water (DW), then mixed with $1.5 \mathrm{~kg}$ soil to be placed in plastic pots. Control pots received the same amount of DW, without addition of $\mathrm{Cu}\left(\mathrm{SO}_{4}\right) \cdot 5 \mathrm{H}_{2} \mathrm{O}$. The prepared pots were incubated for 14 days in a dark room and received tap water to maintain $75 \%$ of the field capacity. The test soil was analyzed for the selected chemical properties using standard methods prior to planting. For instance, phosphorous and total nitrogen were determined by the Olsen $\mathrm{P}$ extracting solution and Kjeldahl measurement method, respectively [29,30], and WalkleyBlack method was used to analyze soil Organic Carbon (OC) [31]. Selected characteristics of the test soil are provided in Table 1.

Table 1. Selected characteristics of the test soils in different phytoremediation treatments.

\begin{tabular}{|c|c|c|c|c|c|c|}
\hline Treatment & $\mathrm{pH}$ & $\begin{array}{c}E C \\
\left(\mathrm{ds} \mathrm{m}^{-1}\right)\end{array}$ & $\begin{array}{l}\text { OC } \\
(\%)\end{array}$ & $\begin{array}{c}\text { Total N } \\
(\%)\end{array}$ & $\begin{array}{c}P \\
\left(\mathrm{mg} \mathrm{kg}^{-1}\right)\end{array}$ & $\begin{array}{c}\text { Total Cu } \\
\left(\mathrm{mg} \mathrm{kg}^{-1}\right)\end{array}$ \\
\hline $\mathrm{T} 1$ (Control) $^{+}$ & $7.81 \pm 0.15 *$ & $1.81 \pm 0.04$ & $0.78 \pm 0.14$ & $0.49 \pm 0.06$ & $8.18 \pm 0.43$ & $32.97 \pm 3.41$ \\
\hline $\mathrm{T} 2\left(50 \mathrm{mg} \mathrm{kg}^{-1} \mathrm{Cu}\right)$ & $7.58 \pm 0.12$ & $1.86 \pm 0.08$ & $0.69 \pm 0.15$ & $0.42 \pm 0.07$ & $7.52 \pm 1.00$ & $80.13 \pm 8.38$ \\
\hline $\mathrm{T} 3\left(100 \mathrm{mg} \mathrm{kg}^{-1} \mathrm{Cu}\right)$ & $7.19 \pm 0.05$ & $1.99 \pm 0.11$ & $0.62 \pm 0.11$ & $0.36 \pm 0.05$ & $6.80 \pm 0.53$ & $135.71 \pm 11.30$ \\
\hline $\mathrm{T} 4\left(200 \mathrm{mg} \mathrm{kg}^{-1} \mathrm{Cu}\right)$ & $6.87 \pm 0.10$ & $2.11 \pm 0.10$ & $0.57 \pm 0.11$ & $0.33 \pm 0.06$ & $5.62 \pm 0.70$ & $219.18 \pm 19.75$ \\
\hline
\end{tabular}

* Values represent mean \pm standard error $(n=3),{ }^{\dagger}$ Soil Texture: Clay content $(27 \%)$, Silt Content $(38 \%)$, and Sand Content (35\%); Clay Loam (CL). T1, T2, T3 and T4 represent Treatment 1, Treatment 2, Treatment 3 and Treatment 4 , respectively.

Acid digestion ( $6 \mathrm{~mL}$ nitric acid and $2 \mathrm{~mL}$ chlorohydric acid) in a microwave reaction system was applied to determine copper content in soil. Extracts were finally analyzed for copper concentration using an atomic absorption spectrophotometry (Perkin Elmer 700, Boston, MA, USA) based on the standard methods [32].

\subsection{Pot Experiments}

Plant seeds were sown in plastic pots containing various levels of copper. Initially, five treatments were considered, namely, T1, T2, T3, T4 and T5 $(n=3)$ with copper contents of 0 , $50,100,200$ and $300 \mathrm{mg} \mathrm{kg}^{-1}$, respectively. Applying $300 \mathrm{mg} \mathrm{kg}^{-1}$ copper almost completely prevented seedling emergence and plant growth in this treatment was negligible, therefore T5 was excluded from the reminder of the experiments and analyses. Z. mays was cultivated in a greenhouse for 42 days, under the natural sunlight. Pots were irrigated twice or thrice a week and monitored daily to evaluate germination rate and plant growth. After harvesting the plants, the roots and shoots were separated carefully, root length and shoot height were measured, then they were placed in an oven for $24 \mathrm{~h}$ at $70{ }^{\circ} \mathrm{C}$ to obtain dry biomass.

\subsection{Analysis of Copper in Plant Roots and Shoots}

Roots and shoots of Z. mays were initially air dried, then oven dried for $12 \mathrm{~h}$ at $60{ }^{\circ} \mathrm{C}$. The dried plant materials were ground to pass a 200 mesh, then extracted using digestion method $\left(4.0 \mathrm{~mL} \mathrm{HNO}_{3}\right.$ and $\left.1.0 \mathrm{~mL} \mathrm{HClO}_{4}\right)$ at $100-230{ }^{\circ} \mathrm{C}$. Filtration of the extracts was 
performed by MILEXHA $0.45 \mu \mathrm{m}$ diameter filter. The total concentration of copper was ultimately analyzed using a Perkin Elmer 700 atomic absorption spectrometer $[33,34]$.

\subsection{Translocation, Bioconcentration, and Bioaccumulation Factors and Phytoremediation Ratio}

The translocation factor (TF) is an important index to evaluate capability of a given plant species to translocate a contaminant from roots to shoots was determined in this study. Z. mays potential to uptake copper from soil was assessed by calculation of bio concentration factor (BCF). Bioaccumulation Coefficient (BAC) was also determined for different treatments in this research. In addition, the phytoextraction efficiency of $Z$. mays was evaluated through determination of phytoremediation ratio (PR) index. $T F, B C F, B A C$, and $P R$ values were determined using the following equations [35,36]:

$$
\begin{gathered}
T F=\frac{\text { Concentration of metal in shoots }}{\text { Concentration of metal in roots }} \\
B C F=\frac{\text { Concentration of metal in roots }}{\text { Concentration of metal in test soil }} \\
B A C=\frac{\text { Concentration of metal in shoots }}{\text { Concentration of metal in test soil }} \\
P R(\%)=\frac{\text { Copper concentration in plant } \times \text { dry biomass of plant }}{\text { Copper concentration in soil } \times \text { Soil weight in each pot }} \times 100
\end{gathered}
$$

\subsection{Statistical Analysis}

In this study, all statistical analyses were performed using IBM SPSS Statistics 24. Standard errors for three replicates are presented (mean $\pm \mathrm{SE} ; n=3$ ). Significance of differences was determined using one-way analysis of variance (ANOVA). Significance level was considered at $p=0.05$.

\section{Results and Discussion}

\subsection{Z. mays Growth}

3.1.1. Germination rate of Z. mays in Copper-Treated Soils

Applying copper concentration of $50 \mathrm{mg} \mathrm{kg}^{-1}$ to soil did not alter seedling emergence in comparision with the control treatment, while gradual increase of copper content in soil reduced seedling emergence. Addition of 100 and $200 \mathrm{mg} \mathrm{kg}^{-1}$ copper significantly lessened germination of $Z$. mays (Figure 1 ).

For instance, the presence of $200 \mathrm{mg} \mathrm{kg}^{-1}$ copper in soil decreased Z. mays germination by $28 \%$ in contrast to the non-contaminated treatment $(p<0.05)$. Ultimately, the application of $300 \mathrm{mg} \mathrm{kg}^{-1}$ copper prevented germination of $Z$. mays in this study. In a study by Amin et al. (2021), the addition of $200 \mathrm{mg} / \mathrm{kg} \mathrm{Cu}$ to soil lessened germination of $A$. sativa by around $55 \%$, while germination of G. max did not occur at the same content of $\mathrm{Cu}$ in soil [35]. Phytotoxicity of heavy metals to plant seeds varies among different plant species. Toxic metals may interfere with enzymes, e.g., protease, thereby accelerate breakdown of stored food materials in plant seeds, which can alter permeability properties of cell membranes [37]. Reduced germination of plant species in presence of excessive quantities of copper in soil has been reported [38]. In this study, delayed emergence of Z. mays seedlings was also occurred due to the application of $200 \mathrm{mg} \mathrm{kg}^{-1} \mathrm{Cu}$ to soil. However, Z. mays exhibited promising toleration in presence of copper in soil in most cases. 


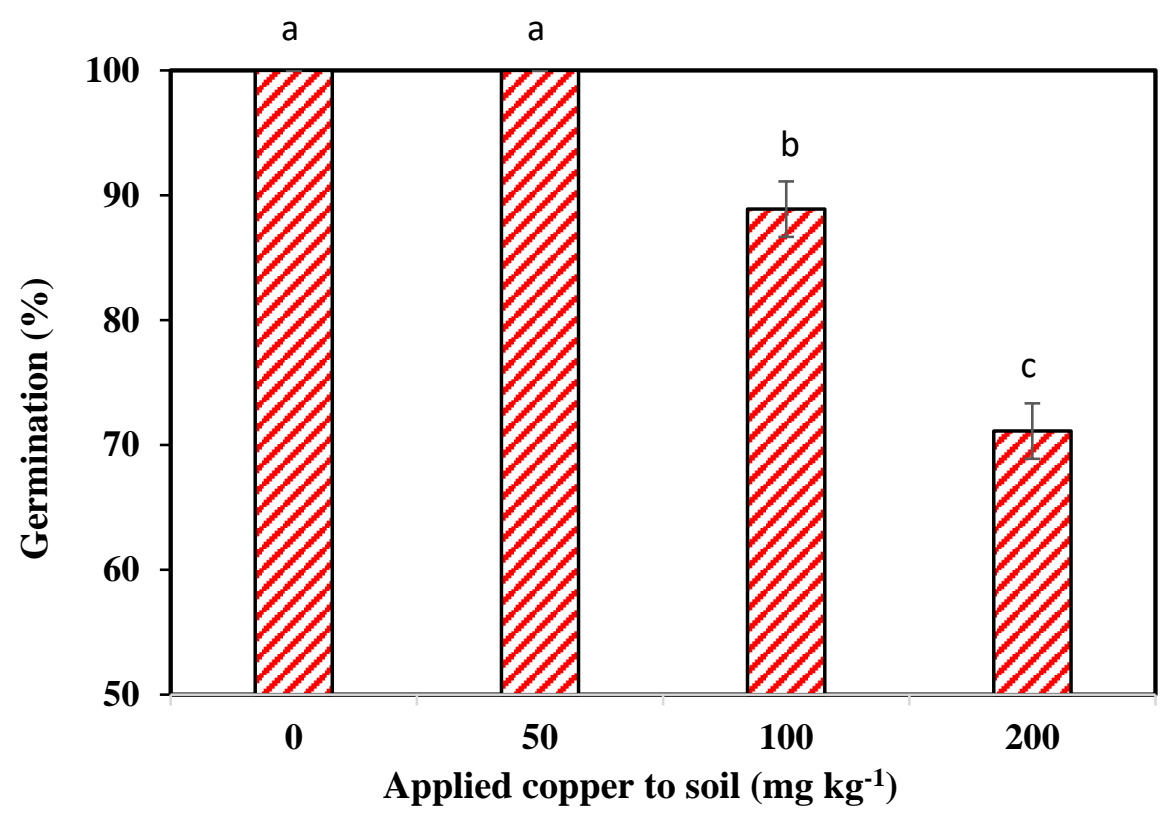

Figure 1. Ultimate germination of Zea mays in contaminated soil with $0,50,100$ and $200 \mathrm{mg} \mathrm{kg}^{-1}$ copper. Mean values that do not share a letter are significantly different at $p=0.05$ (mean \pm S.E.; $n=3)$.

\subsubsection{Copper Toxic Impacts on Growth of Z. mays}

The Z. mays biomass and length were used to evaluate the impacts of different levels of $\mathrm{Cu}$ in soil on plant growth (Figures 2 and 3). Results showed that addition of $50 \mathrm{mg} \mathrm{kg}^{-1}$ $\mathrm{Cu}$ slightly increased plant biomass, in contrast to the control treatment. This is because of the fact that copper is a beneficial micronutrient to plant growth, particularly at low concentrations. However, addition of higher concentrations of $\mathrm{Cu}$ reduced plant biomass in contrast to $\mathrm{T} 1$. Increased $\mathrm{Cu}$ content in soil caused further decrease of root biomass in this study. For instance, addition of $200 \mathrm{mg} \mathrm{kg}^{-1} \mathrm{Cu}$ reduced both root biomass and shoot biomass significantly, in comparison with the control treatment $(p<0.05)$ (Figure 2$)$.

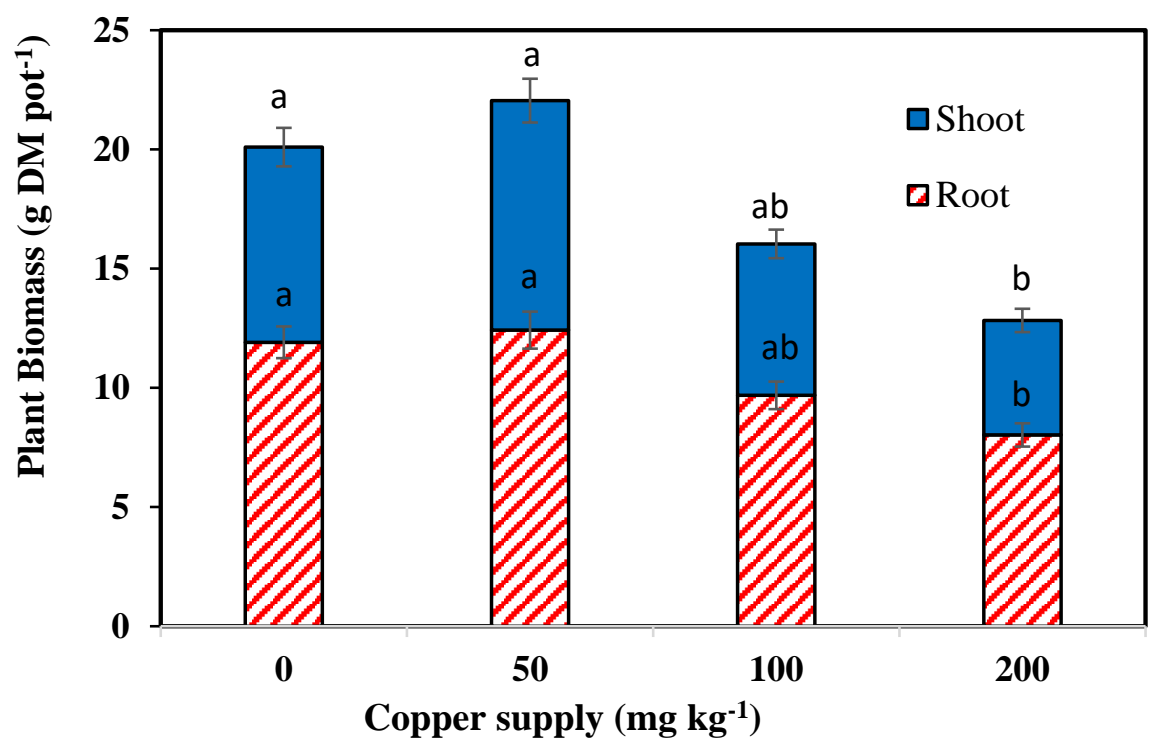

Figure 2. Dried biomass of Zea mays grown in contaminated soil with soil with 0, 50, 100 and $200 \mathrm{mg} \mathrm{kg}^{-1}$ copper after 42 days. Mean values that do not share a letter are significantly different at $p=0.05$ (mean \pm S.E.; $n=3$ ). 


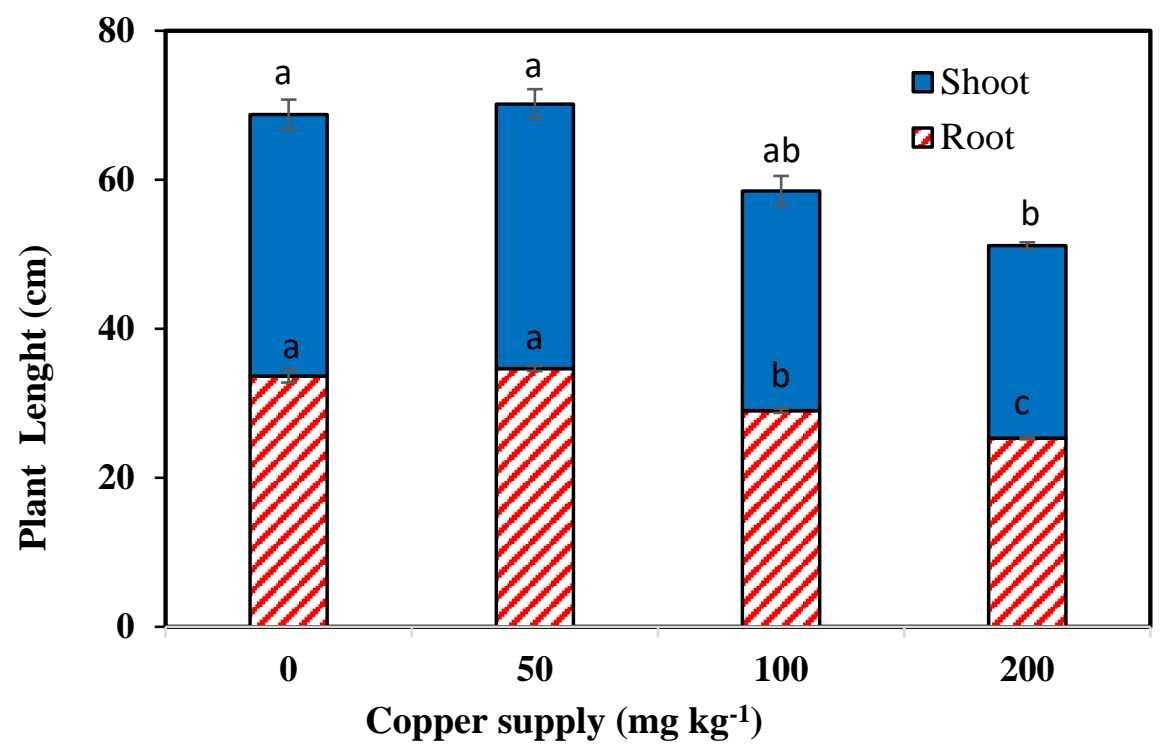

Figure 3. The length of Zea mays grown in contaminated soil with soil with $0,50,100$ and $200 \mathrm{mg} \mathrm{kg}^{-1}$ copper after 42 days. Mean values that do not share a letter are significantly different at $p=0.05$ (mean \pm S.E.; $n=3$ ).

Biomass of the total plant became somewhat enhanced through the addition of $50 \mathrm{mg} \mathrm{kg}^{-1} \mathrm{Cu}$, whereas applying higher copper levels reduced Z. mays biomass. Presence of 100 and $200 \mathrm{mg} \mathrm{kg}^{-1}$ copper in soil reduced root biomass of $Z$. mays by $18.72 \%$ and $32.66 \%$, respectively. Plant growth depression upon occurrence of high levels of heavy metals in soil was suggested to be associated with the plant type, metal speciation and concentration [39]. Heavy metal stress can disturb plant metabolic activities, reduce photosynthesis, and decrease uptake of essential nutrients from soil, which in turn diminish plant biomass establishment [35,40]. For instance, remarkable reduction in $\mathrm{Fe}, \mathrm{Zn}$ and $\mathrm{P}$ uptake in maize cultivated in copper contaminated soil was reported in the literature [41]. Selected plants for phytoremediation are preferred to have fast growth, extensive root development capability, remarkable biomass establishment and high storage capacity for heavy metals [42]. Based on the obtained results, Z. mays seems to be a reasonably tolerant and rapid growing plant which is beneficial in terms of phytoremediation potential. Remarkable biomass establishment is also a crucial factor which can promote phytoremediation potential of plants [43]. Shoot height and root length of Z. mays in different treatments illustrated similar trend as biomass in response to applying different levels of copper to soil and lessened with rising copper content from 100 to $200 \mathrm{mg} \mathrm{kg}^{-1}$ (Figure 3).

The extension of $Z$. mays in T4 with the root length and shoot height of, respectively, $25.3 \pm 0.3 \mathrm{~cm}$ and $25.8 \pm 0.8 \mathrm{~cm}$, was significantly suppressed compared to the plant growth in T1 $(p<0.05)$. Phytotoxicity of excessive amounts of heavy metals in soil has been reported by other authors $[44,45]$. The sensitivity of $Z$. mays biomass and length to the addition of $200 \mathrm{mg} \mathrm{kg}^{-1}$ copper to soil was obtained in this study, while lower levels of copper did not inhibit plant growth significantly $(p>0.05)$. In other words, elongation of $Z$. mays root and shoot indicated a remarkable sensibility to the presence of excessive amounts of $\mathrm{Cu}$ in soil. Heavy metals can adversely affect uptake of nutrients and water, thereby reduce root extension in soil [46]. Migration of metals such as copper from roots to shoots can act on sensible parts of the plants, e.g., leaves and adversely affect photosynthesis process, which can pose plant height reduction [47]. Lower levels of $\mathrm{Cu}$ favoured plant establishment and growth, whereas higher $\mathrm{Cu}$ levels, i.e., 100 and $200 \mathrm{mg} \mathrm{kg}^{-1}$ in soil suppressed Z. mays growth. Additionally, onsite observations indicated that $Z$. mays leaves were withered more rapidly due to applying higher levels of copper. 


\subsection{Copper Uptake and Accumulation in Z. mays Tissues}

Figure 4 shows the distribution of $\mathrm{Cu}$ in the roots and shoots of $Z$. mays for different treatments at the end of the phytoremediation experiment. The average concentrations of $\mathrm{Cu}$ in $\mathrm{Z}$. mays roots were determined to be $56.0,126.4,237.4$ and $435.8 \mathrm{mg} \mathrm{kg}^{-1}$ in amended soils with $0,50,100$, and $200 \mathrm{mg} \mathrm{kg}^{-1}$ copper, respectively. Phytoextraction is the principal mechanism through which metals are eliminated from soil during a phytoremediation process [48]. The results showed that the concentration of $\mathrm{Cu}$ in $\mathrm{Z}$. mays roots and areal parts became enhanced with copper content in soil. For instance, copper concentrations in Z. mays roots and shoots in T4 were $435.8 \mathrm{mg} \mathrm{kg}^{-1}$ and $831.5 \mathrm{mg} \mathrm{kg}^{-1}$ with a significant enhancement of 7.8 and 10.2 times, respectively, compared to T1 $(p<0.05)$. This is consistent with the literature in which an increase in copper content of soil from $20 \mathrm{mg} \mathrm{kg}^{-1}$ to $100 \mathrm{mg} \mathrm{kg}^{-1}$ caused a reduction in maize growth and an increase in copper uptake from soil [49]. This might be attributed to the higher availability of copper in soil to be up taken by plant roots. In other words, increase in bioavailability of $\mathrm{Cu}$ in soil treated with higher $\mathrm{Cu}$ levels could be a probable reason for that phenomenon. Metal speciation in soil is a crucial factor in controlling metal uptake by plants. In this study, soil $\mathrm{pH}$ values decreased with enhanced levels of $\mathrm{Cu}$ in soil (Table 1), which may alter $\mathrm{Cu}$ speciation in soil and make them more accessible to be up taken by roots. Contaminant bioavailability is also a critical factor affecting contaminant toxicity as well as the contaminant accessibility to both soil microbes and plants. For plants to be able to remediate pollutants, they must be accessible by the plant roots, such that plants can act on them [50]. Concentration of copper in $Z$. mays roots were greater than shoots in both treated and non-treated soils, suggesting that $Z$. mays roots are the preferential organ for copper storage. This is consistent with the results reported by Korzeniowska et al. (2011) who found higher concentrations of $\mathrm{Cu}$ and $\mathrm{Zn}$ in maize roots compared to the stems and leaves [51].

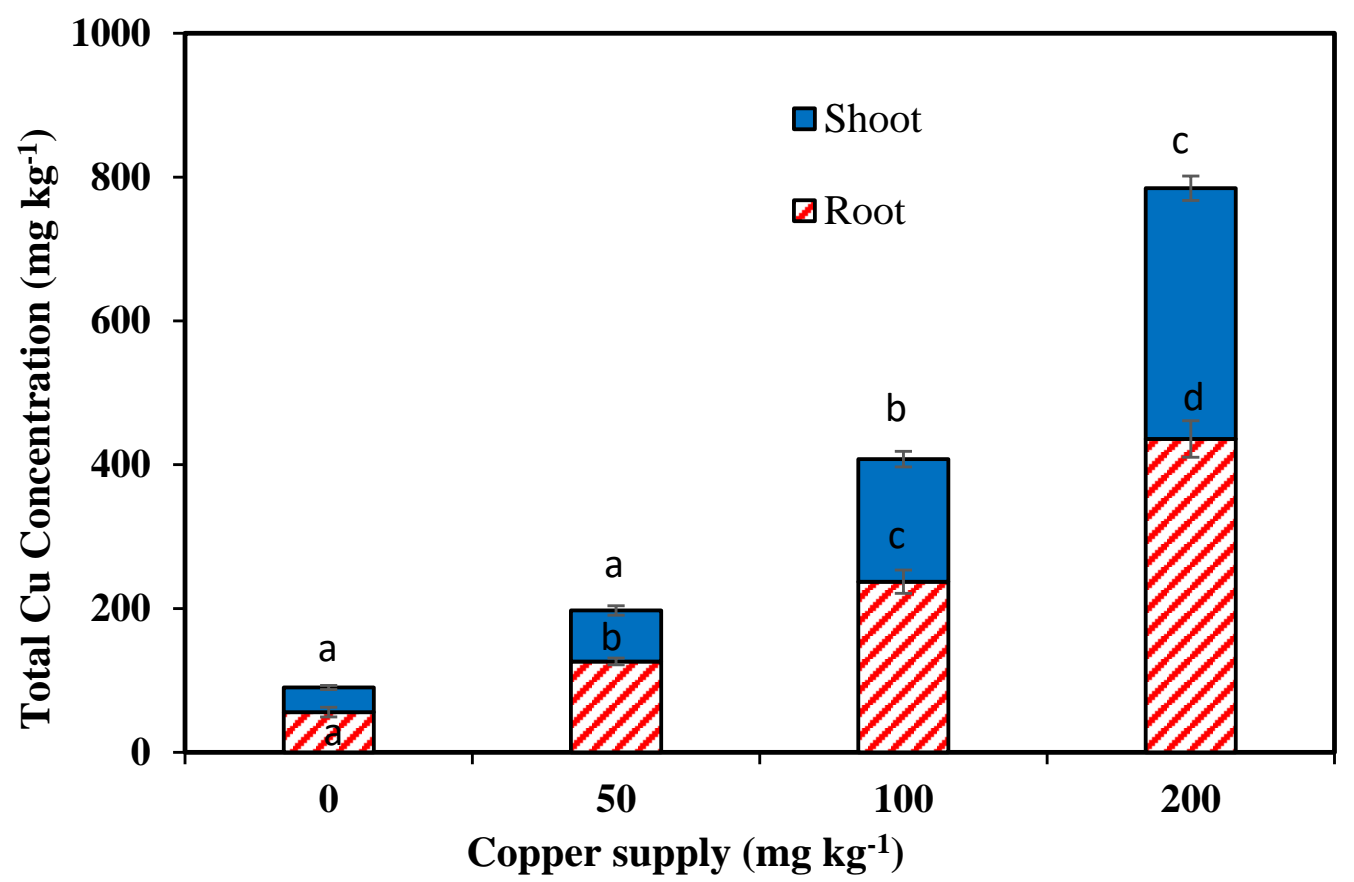

Figure 4. Copper concentration in roots and shoots of Zea mays grown in contaminated soil with soil with $0,50,100$ and $200 \mathrm{mg} \mathrm{kg}^{-1}$ copper. Mean values that do not share a letter are significantly different at $p=0.05$ (mean \pm S.E.; $n=3$ ).

Along with concentrations, copper accumulation in Z. mays tissues is also an important factor that determines phytoremediation capability [52]. Copper accumulation capacity of $Z$. mays depends on both the copper concentration in tissues as well as biomass of a given plant species (Figure 5). Copper accumulation capacity of Z. mays in the control treatment 
was $959.8 \mu \mathrm{g}$ per pot, which was continually increased with $\mathrm{Cu}$ levels in soil. The highest total $\mathrm{Cu}$ accumulation capacity was obtained to be $5210.5 \mu \mathrm{g}$ per pot (T4). Phytoremediation of metals can be promising when considerable concentrations of metals are up taken and accumulated in plant tissues [9]. Phytoremediation mechanisms in remediation of contaminants are mainly complex and not depends only on direct metabolism by plant species [28].

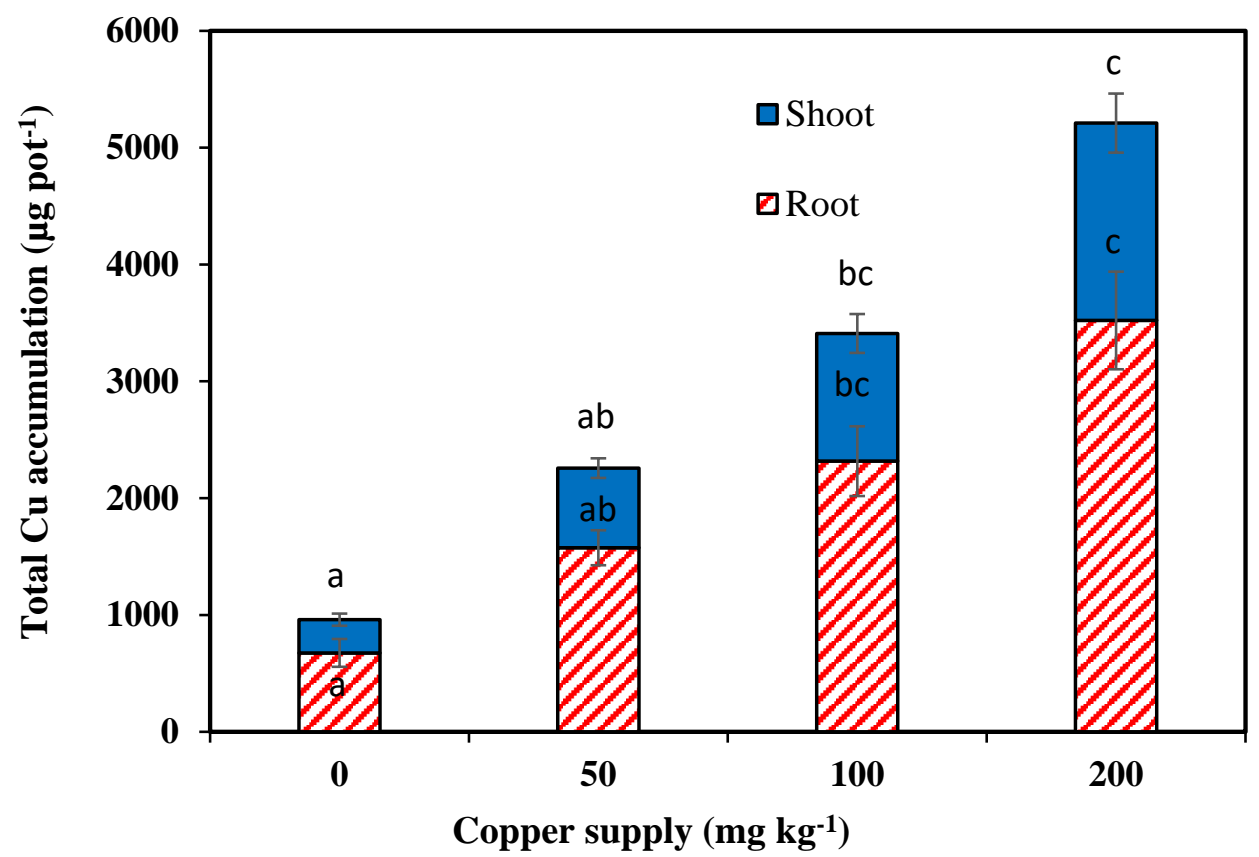

Figure 5. Copper accumulation capacity in Zea mays grown in contaminated soil with soil with 0 , 50,100 and $200 \mathrm{mg} \mathrm{kg}^{-1}$ copper. Mean values that do not share a letter are significantly different at $p=0.05$ (mean \pm S.E.; $n=3$ ).

The accumulation capacity of roots showed similar trend as the areal parts (Figure 5). However, higher accumulation capacity was found in roots rather than shoots, because of higher root biomass as well as greater $\mathrm{Cu}$ concentrations in root. Plant biomass reduction due to the addition of higher concentrations of $\mathrm{Cu}$ to soil did not reduce $\mathrm{Cu}$ accumulation capacity of $Z$. mays, because of the greater impact of enhanced $\mathrm{Cu}$ uptake in corresponding treatments. However, aaccumulation of heavy metals in plant tissues may cause oxidative stress as a result of evolution and accumulation of reactive oxygen species (ROS). Therefore, excessive amounts of copper in soil may bring about remarkable oxidative stress, and therefore remarkable damage to the antioxidant enzymes of plant species. On the other hand, some plant species, e.g., ramie (Boehmeria nivea L.) may activate a detoxification mechanism that partially neutralize the adverse effect of oxidative stress when exposed to copper [53].

Heavy metals at higher levels can also change water balance and assimilation of nutrients, which might ultimately lead to the death of the plant. Moreover, heavy metals in soil may compete with mineral nutrients for adsorption by plant roots. This phenomenon may result in deficiency of essential elements for plant survival, e.g., iron [54,55]. In a previous study, increase in applied concentration of lead in soil promoted its accumulation by plants [56]. To be brief, the obtained results suggested that Z. mays is a suitable plant species for copper extraction from soil and its accumulation in the plant tissues, particularly in presence of higher copper contents in soil, i.e., in T4.

\subsection{Cu phytoextraction Efficiency}

Translocation factors (TF), bio-concentration factors (BCF), and bioaccumulation coefficients $(\mathrm{BCF})$ were determined and are presented in Figure 6 in order to better demonstrate 
the effect of variation of $\mathrm{Cu}$ content on phytoextraction efficiency of Z. mays. BCF and BAC values for most treatments were found to be higher than 1 , while TF values in all the examined treatments were less than 1 , suggesting that phytostabilization is the principal mechanism by which $\mathrm{Cu}$ is remediated by $\mathrm{Z}$. mays. However, $\mathrm{Cu}$ phytoextraction efficiency of $Z$. mays enhanced with $\mathrm{Cu}$ content in soil. In other words, TF values increased in presence of higher levels of $\mathrm{Cu}$, with the greatest value of 0.8 in T4. Occurrence of heavy metals in soil may block the plant root apex, thereby reduce plant capability to transfer heavy metals from roots to the areal parts [57].

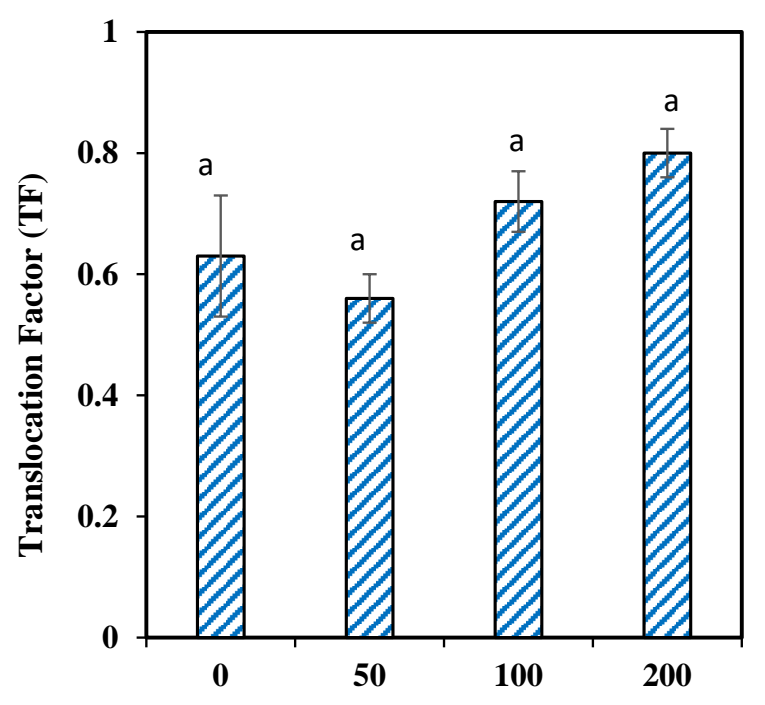

Copper supply $\left(\mathrm{mg} \mathrm{kg}^{-1}\right)$

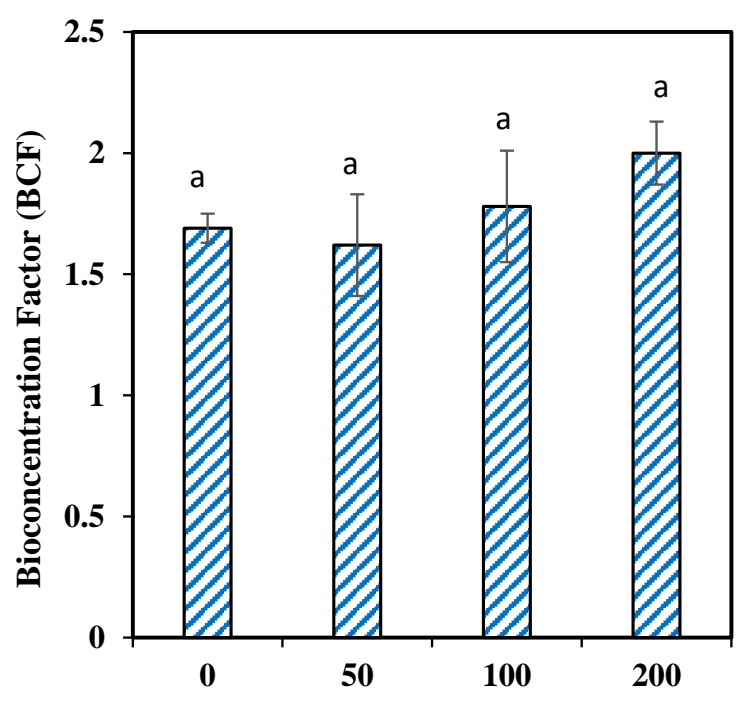

Copper supply $\left(\mathrm{mg} \mathrm{kg}^{-1}\right)$

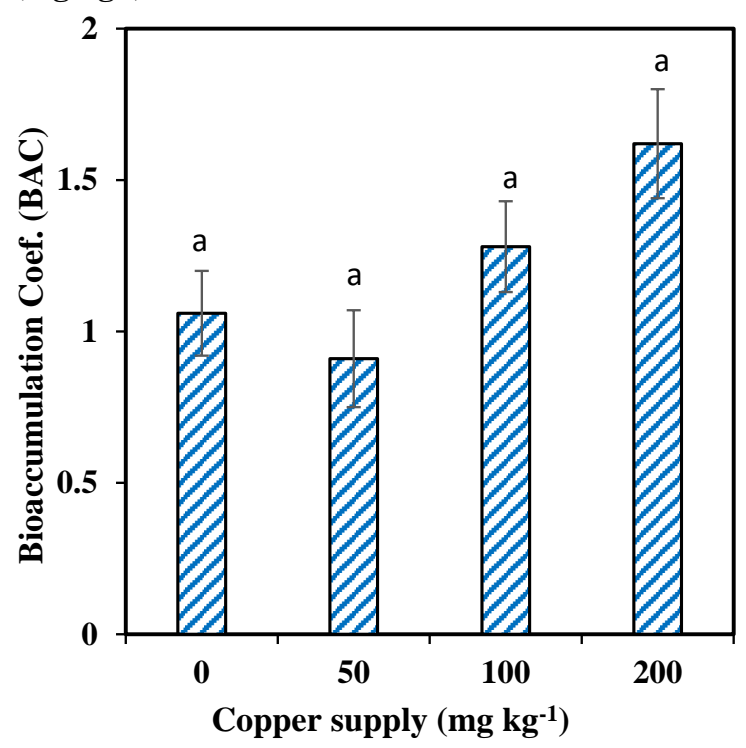

Figure 6. Translocation Factor (TF), Bioconcentration Factor (BCF) and Bioaccumulation Coefficient (BAC) for $\mathrm{Cu}$ in the studied treatments. Mean values that do not share a letter are significantly different at $p=0.05$ (mean \pm S.E.; $n=3$ ).

Moreover, apoplastic barriers might be formed proximate to the root apex in plant species cultivated in heavy metal contaminated soils, which reduces the translocation of sorbed metals from roots to shoots [58]. Using fast growing plant species to remove heavy metals from soil by phytoextraction mechanism has been encouraged in the literature [59]. When suitable plants are employed, heavy metal removal through phytoextraction can be up to ten times less expensive than the conventional remediation techniques, with comparable effectiveness [60]. The following five distinct phases have been recognized for 
phytoextraction: (a) adsorption of some fractions of metals at root surface, (b) sorption of bioavailable fraction of metals via cellular membrane, (c) immobilization of small fraction of sorbed metals by roots in vacuole, (d) entry of mobile metals into the xylem, and (e) migration of metals from roots to the areal parts. Plant biomass enhancement as well as increase in bioavailability of heavy metals in soil matrix can promote phytoextraction efficiency for heavy metals [9,46].

$\mathrm{BCF}$ is known to be an important indicator of heavy metal accumulation capability because the ability of plants to extract heavy metals from soil is taken into consideration for its determination. Results indicate the increased ability of Z. mays to uptake copper from soil when higher concentrations of copper were applied. The highest value of BCF was obtained as be 2.0 in T4. Considerably high BCF values for $\mathrm{Cu}$ in $\mathrm{Z}$. mays has been reported in the literature which is mainly due to the easy uptake of copper from soil by maize [61]. $\mathrm{BAC}$ is also a beneficial factor gaining insight into the ratio of heavy metals accumulated in the areal parts to that in soil. Plants exhibiting BCF values greater than one and TF values less than 1 are suggested to be more suitable candidates to remove metals from soil through phytostabilization [62]. Overall, results suggested that Z. mays can be categorized as $\mathrm{Cu}$ phytostabilizer plant species. Based on the obtained results, $\mathrm{Cu}$ phytoextraction as well as phytostabilization efficiency of $\mathrm{Z}$. mays promoted with elevated levels of $\mathrm{Cu}$ in soil.

\subsection{Phytoremediation Ratio (PR)}

Phytoremediation capability of a given plant may be affected by several factors, e.g., pollutant bioavailability in soil, soil properties, plant type, root exudate composition, etc. The PR values for $Z$. mays grown under different $\mathrm{Cu}$ treatments were determined in this study and are presented in Figure 7. PR values for all the studied treatments were found to be greater than 1\%. The highest PR values was found in T2 (3.7\%) followed by T1 (3.7\%). In other words, an addition of 100 and $200 \mathrm{mg} \mathrm{kg}^{-1} \mathrm{Cu}$ to the soil slightly reduced PR for Z. mays, such that applying $200 \mathrm{mg} \mathrm{kg}^{-1}$ of copper reduced PR by $15.5 \%$, compared to the control treatment. However, the differences found among the studied treatments were not statistically significant $(p>0.05)$. The capability of a given plant species in removing heavy metals from soil depends on biomass establishment as well as metal uptake and accumulation ability. Overall, the results indicated that Z. mays is a phytoremediator plant with a high capability to remove $\mathrm{Cu}$ from soil.

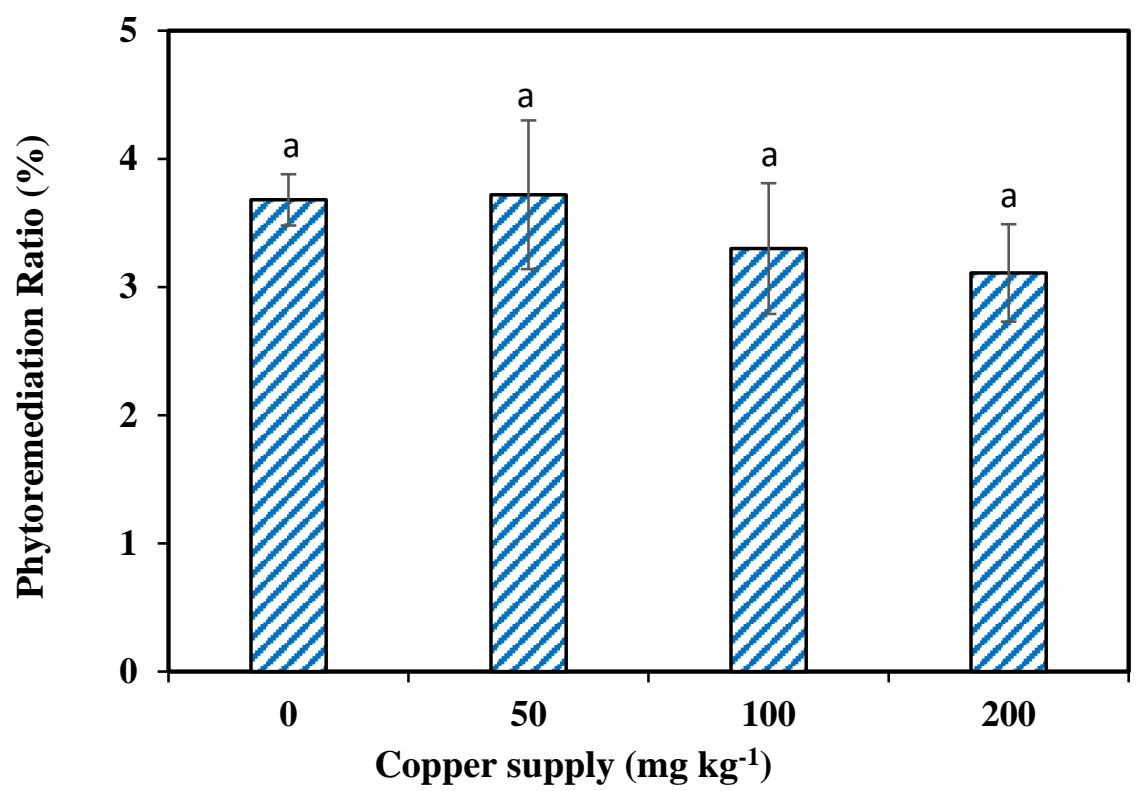

Figure 7. Phytoremediation Ratio (PR) for $\mathrm{Cu}$ in the studied treatments. Mean values that do not share a letter are significantly different at $p=0.05$ (mean \pm S.E.; $n=3$ ). 


\section{Conclusions}

The increasing occurrence of copper in soil can endanger food safety for the upcoming years, which necessitates the application of eco-friendly and effective approaches to remove excessive amounts of copper from soil. Copper uptake from soil by Z. mays and accumulation capacity of its roots and shoots have not been investigated extensively and have therefore been addressed in this research. This study investigated the capability of $Z$. mays to remediate soil contaminated with different levels of copper. The results indicate that $Z$. mays is a promising plant species to remediate $\mathrm{Cu}$ from soil contaminated with low to medium levels of $\mathrm{Cu}$. Furthermore, we found that $\mathrm{Z}$. mays is a tolerant plant and could establish considerable biomass over the period of the experiment. The addition of low concentrations of $\mathrm{Cu}$, i.e., $50 \mathrm{mg} \mathrm{kg}^{-1}$ supported $\mathrm{Z}$. mays growth compared to the control treatment. However, the greater levels of $\mathrm{Cu}$ in soil exhibited adverse effects on plant growth. An addition of $\mathrm{Cu}$ to soil (50-200 $\mathrm{mg} \mathrm{kg}^{-1}$ ) enhanced $\mathrm{Cu}$ concentration in $Z$. mays roots and shoots, compared to the control treatment. Higher concentrations of the applied $\mathrm{Cu}$ to soil effectively enhanced the capacity of $Z$. mays for copper. Greater accumulation of copper in $Z$. mays roots rather than the shoots for all treatments suggesting that phytostabilization might be the principal mechanism in phytoremediation of copper using Z. mays. Along with phytostabilization, $\mathrm{Cu}$ phytoextraction efficiency was also boosted by applying higher concentrations of $\mathrm{Cu}$ to soil. High values of BAC, BCF and PR suggested that $Z$. mays is a promising plant to uptake and accumulate $\mathrm{Cu}$ from soil. Overall, phytoremediation of copper contaminated soils by Z. mays was found to be promising approach to manage copper-contaminated soils, particularly at low to moderate $\mathrm{Cu}$ levels.

Author Contributions: Conceptualization, A.D.Z. and K.H.M.; Data curation, A.D.Z. and K.H.M.; Formal analysis, A.D.Z.; Investigation, A.D.Z.; Methodology, A.D.Z.; Project administration, K.H.M.; Validation, K.H.M.; Writing—original draft, A.D.Z. and K.H.M.; Writing—review and editing, A.D.Z. and K.H.M. All authors have read and agreed to the published version of the manuscript.

Funding: This research received no external funding.

Institutional Review Board Statement: Not applicable.

Informed Consent Statement: Not applicable.

Data Availability Statement: All the relevant data is included in the article.

Acknowledgments: The authors would like to sincerely thank the Alexander von Humboldt Foundation to provide financial sponsorship for a collaboration.

Conflicts of Interest: There is no conflict of interest.

\section{References}

1. Kleckerova, A.; Docekalová, H. Dandelion plants as a biomonitor of urban area contamination by heavy metals. Int. J. Environ. Res. 2014, 8, 157-164.

2. Zand, A.D.; Hoveidi, H. Evaluation of the Potential of Burningbush (Kochia scoparia (L.) Schard) and Maize (Zea mays L.) and the Role of Soil Organic Amendment in Phytoremediation of Gasoline-Contaminated Soils. Int. J. Environ. Res. 2018, 12, 327-336. [CrossRef]

3. Sarwar, N.; Imran, M.; Shaheen, M.R.; Ishaque, W.; Kamran, M.A.; Matloob, A.; Rehim, A.; Hussain, S. Phytoremediation strategies for soils contaminated with heavy metals: Modifications and future perspectives. Chemosphere 2017, 171, 710-721. [CrossRef] [PubMed]

4. Maurya, P.K.; Malik, D.; Yadav, K.K.; Kumar, A.; Kumar, S.; Kamyab, H. Bioaccumulation and potential sources of heavy metal contamination in fish species in River Ganga basin: Possible human health risks evaluation. Toxicol. Rep. 2019, 6, $472-481$. [CrossRef]

5. Jaishankar, M.; Tseten, T.; Anbalagan, N.; Mathew, B.B.; Beeregowda, K.N. Toxicity, mechanism and health effects of some heavy metals. Interdiscip. Toxicol. 2014, 7, 60. [CrossRef] [PubMed]

6. Järup, L. Hazards of heavy metal contamination. Br. Med. Bull. 2003, 68, 167-182. [CrossRef] [PubMed]

7. Kumar, S.; Prasad, S.; Yadav, K.K.; Shrivastava, M.; Gupta, N.; Nagar, S.; Bach, Q.-V.; Kamyab, H.; Khan, S.A.; Yadav, S. Hazardous heavy metals contamination of vegetables and food chain: Role of sustainable remediation approaches-A review. Environ. Res. 2019, 179, 108792. [CrossRef] [PubMed] 
8. He, Z.; Shentu, J.; Yang, X.; Baligar, V.C.; Zhang, T.; Stoffella, P.J. Heavy metal contamination of soils: Sources, indicators and assessment. J. Environ. Indic. 2015, 9, 17-18.

9. Ashraf, S.; Ali, Q.; Zahir, Z.A.; Ashraf, S.; Asghar, H.N. Phytoremediation: Environmentally sustainable way for reclamation of heavy metal polluted soils. Ecotoxicol. Environ. Saf. 2019, 174, 714-727. [CrossRef] [PubMed]

10. McLaughlin, M.J.; Hamon, R.; McLaren, R.; Speir, T.; Rogers, S. A bioavailability-based rationale for controlling metal and metalloid contamination of agricultural land in Australia and New Zealand. Soil Res. 2000, 38, 1037-1086. [CrossRef]

11. Missimer, T.M.; Teaf, C.M.; Beeson, W.T.; Maliva, R.G.; Woolschlager, J.; Covert, D.J. Natural background and anthropogenic arsenic enrichment in Florida soils, surface water, and groundwater: A review with a discussion on public health risk. Int. J. Environ. Res. Public Health 2018, 15, 2278. [CrossRef] [PubMed]

12. Wu, F.-B.; Chen, F.; Wei, K.; Zhang, G.-P. Effect of cadmium on free amino acid, glutathione and ascorbic acid concentrations in two barley genotypes (Hordeum vulgare L.) differing in cadmium tolerance. Chemosphere 2004, 57, 447-454. [CrossRef] [PubMed]

13. Adrees, M.; Ali, S.; Rizwan, M.; Ibrahim, M.; Abbas, F.; Farid, M.; Zia-ur-Rehman, M.; Irshad, M.K.; Bharwana, S.A. The effect of excess copper on growth and physiology of important food crops: A review. Environ. Sci. Pollut. Res. 2015, 22, 8148-8162. [CrossRef] [PubMed]

14. Dučić, T.; Milenković, I.; Mutavdžić, D.; Nikolić, M.; de Yuso, M.V.M.; Vučinić, Ž.; Algarra, M.; Radotić, K. Estimation of carbon dots amelioration of copper toxicity in maize studied by synchrotron radiation-FTIR. Colloids Surf. B Biointerfaces 2021, 204, 111828. [CrossRef] [PubMed]

15. Mantovi, P.; Bonazzi, G.; Maestri, E.; Marmiroli, N. Accumulation of copper and zinc from liquid manure in agricultural soils and crop plants. Plant Soil 2003, 250, 249-257. [CrossRef]

16. Gang, A.; Vyas, A.; Vyas, H. Toxic effect of heavy metals on germination and seedling growth of wheat. J. Environ. Res. Dev. 2013, $8,206-213$

17. Xu, J.; Yang, L.; Wang, Z.; Dong, G.; Huang, J.; Wang, Y. Effects of soil copper concentration on growth, development and yield formation of rice (Oryza sativa). Rice Sci. 2005, 12, 125.

18. Jaiswal, A.; Verma, A.; Jaiswal, P. Detrimental effects of heavy metals in soil, plants, and aquatic ecosystems and in humans. $J$. Environ. Pathol. Toxicol. Oncol. 2018, 37, 183-197. [CrossRef]

19. Shrivastava, A. A review on copper pollution and its removal from water bodies by pollution control technologies. Indian J. Environ. Prot. 2009, 29, 552-560.

20. Lone, M.I.; He, Z.-1.; Stoffella, P.J.; Yang, X.-e. Phytoremediation of heavy metal polluted soils and water: Progresses and perspectives. J. Zhejiang Univ. Sci. B 2008, 9, 210-220. [CrossRef]

21. Hechmi, N.; Aissa, N.B.; Abdennaceur, H.; Jedidi, N. Phytoremediation potential of maize (Zea mays L.) in co-contaminated soils with pentachlorophenol and cadmium. Int. J. Phytoremediat. 2013, 15, 703-713. [CrossRef] [PubMed]

22. Rodrigo Miyazaki, F.; Pilecco, M.; Bigaton, D. Foliar copper uptake by maize plants: Effects on growth and yield. Ciênc. Rural 2013, 43, 1561-1568.

23. Macek, T.; Macková, M.; Káš, J. Exploitation of plants for the removal of organics in environmental remediation. Biotechnol. Adv. 2000, 18, 23-34. [CrossRef]

24. Sharma, S.; Rana, S.; Thakkar, A.; Baldi, A.; Murthy, R.; Sharma, R. Physical, chemical and phytoremediation technique for removal of heavy metals. J. Heavy Met. Toxic. Dis. 2016, 1, 1-15.

25. Chua, J.; Banua, J.M.; Arcilla, I.; Orbecido, A.; de Castro, M.E.; Ledesma, N.; Deocaris, C.; Madrazo, C.; Belo, L. Phytoremediation potential and copper uptake kinetics of Philippine bamboo species in copper contaminated substrate. Heliyon 2019, 5, e02440. [CrossRef]

26. Wuana, R.A.; Okieimen, F.E. Heavy metals in contaminated soils: A review of sources, chemistry, risks and best available strategies for remediation. Int. Sch. Res. Not. 2011, 2011, 402647. [CrossRef]

27. Pilon-Smits, E. Phytoremediation. Annu. Rev. Plant Biol. 2005, 56, 15-39. [CrossRef]

28. Singh, O.; Jain, R. Phytoremediation of toxic aromatic pollutants from soil. Appl. Microbiol. Biotechnol. 2003, 63, 128-135. [CrossRef]

29. Burt, R. Kellogg Soil Survey Laboratory Methods Manual; United States Department of Agriculture, Natural Resources Conservation: Washington, DC, USA, 2014.

30. Dewis, J.; Freitas, F. Physical and Chemical Methods of Soil and Water Analysis; FAO Soils Bulletin: Rome, Italy, 1970.

31. Walkley, A.; Black, I.A. An examination of the Degtjareff method for determining soil organic matter, and a proposed modification of the chromic acid titration method. Soil Sci. 1934, 37, 29-38. [CrossRef]

32. Gil-Díaz, M.; Pinilla, P.; Alonso, J.; Lobo, M. Viability of a nanoremediation process in single or multi-metal (loid) contaminated soils. J. Hazard. Mater. 2017, 321, 812-819. [CrossRef]

33. Wannaz, E.D.; Carreras, H.A.; Abril, G.A.; Pignata, M.L. Maximum values of $\mathrm{Ni}^{2+}, \mathrm{Cu}^{2+}, \mathrm{Pb}^{2+}$ and $\mathrm{Zn}^{2+}$ in the biomonitor Tillandsia capillaris (Bromeliaceae): Relationship with cell membrane damage. Environ. Exp. Bot. 2011, 74, 296-301. [CrossRef]

34. Fang, R. Application of Atomic Absorption Spectroscopy in Sanitary Test; Beijing University Press: Beijing, China, 1991; Volume 15, pp. $148-158$.

35. Amin, H.; Arain, B.A.; Jahangir, T.M.; Abbasi, A.R.; Mangi, J.; Abbasi, M.S.; Amin, F. Copper (Cu) tolerance and accumulation potential in four native plant species: A comparative study for effective phytoextraction technique. Geol. Ecol. Landsc. 2021, 5, 53-64. [CrossRef] 
36. Embrandiri, A.; Rupani, P.; Shahadat, M.; Singh, R.; Ismail, S.; Ibrahim, M.; Kadir, M.A. The phytoextraction potential of selected vegetable plants from soil amended with oil palm decanter cake. Int. J. Recycl. Org. Waste Agric. 2017, 6, 37-45. [CrossRef]

37. Singh, D.; Nath, K.; Sharma, Y.K. Response of wheat seed germination and seedling growth under copper stress. J. Environ. Biol. 2007, 28, 409 .

38. Htwe, T.; Onthong, J.; Duangpan, S.; Techato, K.; Chotikarn, P.; Sinutok, S. Effect of Copper Contamination on Plant Growth and Metal Contents in Rice Plant (Oryza Sativa L.). Commun. Soil Sci. Plant Anal. 2020, 51, 2349-2360. [CrossRef]

39. Sekara, A.; Poniedzialeek, M.; Ciura, J.; Jedrszczyk, E. Zinc and copper accumulation and distribution in the tissues of nine crops: Implications for phytoremediation. Pol. J. Environ. Stud. 2005, 14, 829-835.

40. Li, X.; Yang, Y.; Zhang, J.; Jia, L.; Li, Q.; Zhang, T.; Qiao, K.; Ma, S. Zinc induced phytotoxicity mechanism involved in root growth of Triticum aestivum L. Ecotoxicol. Environ. Saf. 2012, 86, 198-203. [CrossRef]

41. Azeez, M.; Adesanwo, O.; Adepetu, J. Effect of Copper (Cu) application on soil available nutrients and uptake. Afr. J. Agric. Res. 2015, 10, 359-364.

42. Sytar, O.; Brestic, M.; Taran, N.; Zivcak, M. Plants used for biomonitoring and phytoremediation of trace elements in soil and water. In Plant Metal Interaction; Elsevier: Amsterdam, The Netherlands, 2016; pp. 361-384.

43. Chen, Z.-J.; Tian, Y.-H.; Zhang, Y.; Song, B.-R.; Li, H.-C.; Chen, Z.-H. Effects of root organic exudates on rhizosphere microbes and nutrient removal in the constructed wetlands. Ecol. Eng. 2016, 92, 243-250. [CrossRef]

44. Napoli, M.; Cecchi, S.; Grassi, C.; Baldi, A.; Zanchi, C.A.; Orlandini, S. Phytoextraction of copper from a contaminated soil using arable and vegetable crops. Chemosphere 2019, 219, 122-129. [CrossRef]

45. Huang, R.; Dong, M.; Mao, P.; Zhuang, P.; Paz-Ferreiro, J.; Li, Y.; Li, Y.; Hu, X.; Netherway, P.; Li, Z. Evaluation of phytoremediation potential of five Cd (hyper) accumulators in two Cd contaminated soils. Sci. Total Environ. 2020, 721, 137581. [CrossRef] [PubMed]

46. Adrees, M.; Ali, S.; Rizwan, M.; Zia-ur-Rehman, M.; Ibrahim, M.; Abbas, F.; Farid, M.; Qayyum, M.F.; Irshad, M.K. Mechanisms of silicon-mediated alleviation of heavy metal toxicity in plants: A review. Ecotoxicol. Environ. Saf. 2015, 119, 186-197. [CrossRef] [PubMed]

47. Singh, S.; Parihar, P.; Singh, R.; Singh, V.P.; Prasad, S.M. Heavy metal tolerance in plants: Role of transcriptomics, proteomics, metabolomics, and ionomics. Front. Plant Sci. 2016, 6, 1143. [CrossRef] [PubMed]

48. Bhargava, A.; Carmona, F.F.; Bhargava, M.; Srivastava, S. Approaches for enhanced phytoextraction of heavy metals. J. Environ. Manag. 2012, 105, 103-120. [CrossRef]

49. Wyszkowski, M.; Brodowska, M.S. Phytoextraction with Maize of Soil Contaminated with Copper after Application of Mineral and Organic Amendments. Agronomy 2020, 10, 1597. [CrossRef]

50. Allard, A.-S.; Remberger, M.; Neilson, A.H. The negative impact of aging on the loss of PAH components in a creosotecontaminated soil. Int. Biodeterior. Biodegrad. 2000, 46, 43-49. [CrossRef]

51. Korzeniowska, J.; Stanislawska-Glubiak, E.; Igras, J. Applicability of energy crops for metal phytostabilization of soils moderately contaminated with copper, nickel and zinc. J Food Agric. Environ. 2011, 9, 693-697.

52. Zaier, H.; Ghnaya, T.; Lakhdar, A.; Baioui, R.; Ghabriche, R.; Mnasri, M.; Sghair, S.; Lutts, S.; Abdelly, C. Comparative study of $\mathrm{Pb}$-phytoextraction potential in Sesuvium portulacastrum and Brassica juncea: Tolerance and accumulation. J. Hazard. Mater. 2010, 183, 609-615. [CrossRef]

53. Rehman, M.; Maqbool, Z.; Peng, D.; Liu, L. Morpho-physiological traits, antioxidant capacity and phytoextraction of copper by ramie (Boehmeria nivea L.) grown as fodder in copper-contaminated soil. Environ. Sci. Pollut. Res. 2019, 26, 5851-5861. [CrossRef]

54. Shu, X.; Yin, L.; Zhang, Q.; Wang, W. Effect of Pb toxicity on leaf growth, antioxidant enzyme activities, and photosynthesis in cuttings and seedlings of Jatropha curcas L. Environ. Sci. Pollut. Res. 2012, 19, 893-902. [CrossRef]

55. Huang, C.; Lai, C.; Xu, P.; Zeng, G.; Huang, D.; Zhang, J.; Zhang, C.; Cheng, M.; Wan, J.; Wang, R. Lead-induced oxidative stress and antioxidant response provide insight into the tolerance of Phanerochaete chrysosporium to lead exposure. Chemosphere 2017, 187, 70-77. [CrossRef] [PubMed]

56. Sun, Y.; Zhou, Q.; Wang, L.; Liu, W. The influence of different growth stages and dosage of EDTA on Cd uptake and accumulation in Cd-hyperaccumulator (Solanum nigrum L.). Bull. Environ. Contam. Toxicol. 2009, 82, 348-353. [CrossRef] [PubMed]

57. Wang, S.; Shi, X.; Sun, H.; Chen, Y.; Pan, H.; Yang, X.; Rafiq, T. Variations in metal tolerance and accumulation in three hydroponically cultivated varieties of Salix integra treated with lead. PLoS ONE 2014, 9, e108568. [CrossRef] [PubMed]

58. El-Temsah, Y.S.; Sevcu, A.; Bobcikova, K.; Cernik, M.; Joner, E.J. DDT degradation efficiency and ecotoxicological effects of two types of nano-sized zero-valent iron (nZVI) in water and soil. Chemosphere 2016, 144, 2221-2228. [CrossRef] [PubMed]

59. Pajević, S.; Borišev, M.; Nikolić, N.; Arsenov, D.D.; Orlović, S.; Župunski, M. Phytoextraction of heavy metals by fast-growing trees: A review. Phytoremediation 2016, 29-64. [CrossRef]

60. Wan, X.; Lei, M.; Chen, T. Cost-benefit calculation of phytoremediation technology for heavy-metal-contaminated soil. Sci. Total Environ. 2016, 563, 796-802. [CrossRef]

61. Aladesanmi, O.T.; Oroboade, J.G.; Osisiogu, C.P.; Osewole, A.O. Bioaccumulation factor of selected heavy metals in Zea mays. J. Health Pollut. 2019, 9, 191207.

62. Mendez, M.O.; Maier, R.M. Phytostabilization of mine tailings in arid and semiarid environments-an emerging remediation technology. Environ. Health Perspect. 2008, 116, 278-283. [CrossRef] 